
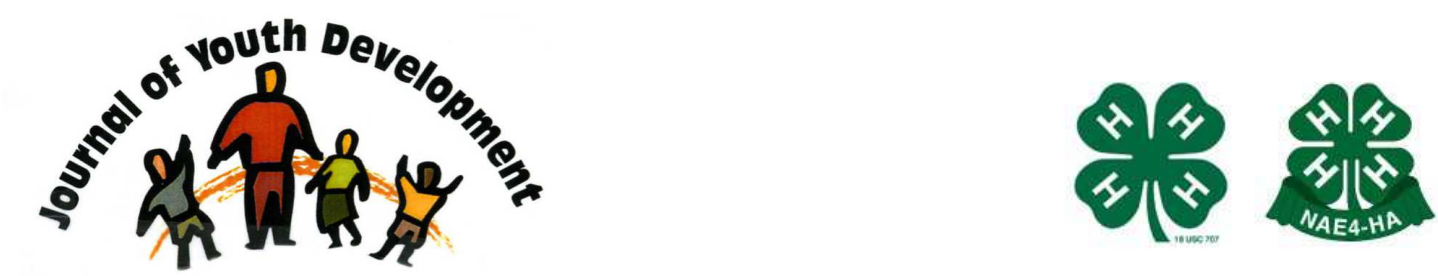

Bridging Research \& Practice

\title{
Camp Counseling and the Development and Transfer of Workforce Skills: The Perspective of Ohio 4-H Camp Counselor Alumni
}

\author{
Janel K. Digby \\ Family \& Consumer Sciences Teacher \\ Elmwood Local Schools \\ Bloomdale, $\mathrm{OH}$ \\ jk digby@yahoo.com \\ Theresa M. Ferrari \\ 4-H Youth Development \\ Ohio State University Extension \\ Columbus, $\mathrm{OH}$ \\ ferrari.8@osu.edu
}




\title{
JOURNAL OF YOUTH DEVELOPMENT \\ bridging research and practice
}

Volume 2, Number 2, Fall 2007

Article 0702FA007

\section{Camp Counseling and the Development and Transfer of Workforce Skills: The Perspective of Ohio 4-H Camp Counselor Alumni}

\author{
Janel K. Digby \\ Elmwood Local Schools \\ Theresa M. Ferrari \\ Ohio State University Extension
}

\begin{abstract}
Recent research shows that camp counselors, including those in 4- $\mathrm{H}$, benefit from the experience by developing important life skills. However, because research regarding the perception of workforce skill development in this context has yielded inconsistent findings, the present study used focus groups to examine 4-H camp counselor alumni perceptions about the skills gained and transfer of these skills to other settings. Overall, 4-H camp counselor alumni thought their experience was fun and enjoyable, yet challenging. They believed they developed important life and workforce skills. Not only did alumni learn these skills, but the skills transferred beyond the camp setting. Leadership was noted as the skill most frequently applied to other contexts. Alumni believed that their counseling experiences had both indirect and direct impacts on their career choice. This study suggests many practical applications for those who work with camp programs.
\end{abstract}

\section{Introduction and Review of Literature}

Camping is an important delivery mode for $4-\mathrm{H}$ programs. However, a review of the camping literature shows that, until recently, more research has examined camper outcomes (e.g., American Camp Association, 2005; Arnold, Bourdeau, \& Nagele, 2005; Garst, \& Bruce, 2003) rather than those for camp counselors.

Overall, studies show that camp counselors benefit from the experience in a variety of ways (DeGraff, \& Edington, 1992; DeGraff, \& Glover, 2003; Dworken, 2004; James, 2003; Powell, 
Bixler, \& Switzer, 2003; Toupence, \& Townsend, 2000). Consistent with this research, recent studies suggest that 4-H camp counselors develop important life skills (Brandt, 2005; Forsythe, Matysik, \& Nelson, 2004; Garst, \& Johnson, 2003, 2005; George, \& Bird, 2006; McNeely, 2004; Purcell, 1996; Weese, 2002). The development of life skills has been consistent across a variety of research methods (e.g., open-ended interviews, focus groups, and surveys) and with varied intensity of the camping activity (from a four- or five-day camp to an entire summer season).

Findings related to whether camp counselors made career and workforce connections from their experience are mixed. On the one hand, results indicate that camp counselors believed the camp counseling experience was preparing them for a future job and leadership roles in their community (Forsythe, et al., 2004). However, other studies showed only a moderate understanding of the camp experience in relation to its connections to the world of work (McNeely, 2004) or a belief that the camp counseling experience did not encourage consideration of a career working with children (Brandt, 2005). One difference between the 4-H and non-4-H studies is that both DeGraaf and Glover (2003) and Dworken (2004) studied alumni who were adults when they worked as camp staff compared with the teen camp counselors that characterize many 4-H county-based camping programs, including Ohio. A more general study of 4- $\mathrm{H}$ alumni found that they believed 4-H had impacted their educational training and their choice of career (McKinley, 1999). Likewise, studies of non-4-H audiences have found that camp counseling influenced career choice (DeGraff, \& Glover, 2003; Dworken, 2004). These conflicting results suggest that this is a topic worthy of further examination.

Preparing youth for the workforce is a major concern in U.S. society (Casner-Lotto, \& Barrington, 2006; Ferrari, 2003; Schwarz, \& Kay, 2006). In the last 30 years, the skills required for youth to succeed in the economy have changed radically, but the skills emphasized in schools have not changed at the same pace (Murnane, \& Levy, 1996; SCANS, 1991). Thus, youth lack the skills essential for job success and are entering the workplace unprepared (Casner-Lotto, \& Barrington, 2006). The Secretary's Commission on Achieving Necessary Skills (SCANS) report (1991) from the Department of Labor concluded that American high school students need to develop a new set of competencies and foundation skills if they want to enjoy a productive and satisfying work life. In addition to academic skills, several authors have written about the new basic skills needed by today's workers (Casner-Lotto, \& Barrington, 2006; Levy, \& Murnane, 2006; Murnane, \& Levy, 1996; Partnership for $21^{\text {st }}$ Century Skills, 2003; Pittman, Irby, Yohalem, \& Wilson-Ahlstrom, 2004; SCANS, 1991). These new basic skills include those such as communicating problem solving, and working with others.

The focus on developing skills for the workforce comes at a time when public schools are experiencing increased pressure to meet academic standards and thus may have little time to focus on workforce skills. In fact, after-school and out-of-school programs have been suggested as the ideal place to focus on developing $21^{\text {st }}$ century skills (Schwarz, \& Stolow, 2006). Furthermore, a recent report highlighted the potential for 4- $\mathrm{H}$ to make a positive impact on the state's economy (Battelle Memorial Institute, 2005). We believe the camp setting provides a context in which workforce skills may be developed. As well, serving as a camp counselor has been identified as a positive developmental experience (Ferrari, \& McNeely, 2007). Ohio 4-H invests significant time and effort in its camping program, and camping is a priority area at the state level. Thus, additional study of workforce connections made by camp counselors was deemed appropriate. 


\section{Theoretical Framework}

This study examined camp counseling from the perspective of Bronfenbrenner's ecology of human development (1979; Bronfenbrenner, \& Morris, 1998). That is, camp represents a microsystem which, in addition to a physical place, is comprised of activities, roles, and interpersonal relationships within the setting. These activities, roles, and relationships are growth inducing when they occur over time and become consistently more complex. Likewise, the camping program consists of the total of all experiences, where the unstructured and informal aspects of camp life are as significant as the organized activities. Residential camps that are organized around working and living in small groups afford the opportunity to learn cooperation and teamwork by living it. As noted by Mitchell and Meier (1983), "living fully in the camp community leads participants into a complete range of relationships, experiences and activities that are part of social and educational growth" (p. 4). Furthermore, McNeely (2004) described the camp counseling experience as more than the actual time spent at camp; it also includes the process of selection, training, and planning undertaken before arriving at the camp facility. All of these elements comprise the camp microsystem.

This study also incorporates the perspective of transfer of learning. Transfer has been described as the ultimate goal in teaching and at the same time is regarded as one of teaching's most difficult problems (Haskell, 2001; Macaulay, 2000). Mayer and Wittrock (1996) defined transfer as "when a person's prior experience and knowledge affect learning or problem solving in a new situation" (p. 48). The transfer of skills from camp to the workforce would be an example of far transfer, that is, it involves learning skills and knowledge in one context and applying it to one different from that in which it was learned (Haskell, 2001). Although certain conditions or strategies make transfer of learning more likely, it does not always occur (Salomon, \& Perkins, 1989). There is support in the literature that the best way to learn is through actual experience (Cafarella, 2002; Carlson, \& Maxa, 1998). Among the other strategies suggested within the transfer of learning and experiential learning literature are having opportunities for practice (Nokes, \& Ohlsson, 2005), developing an action plan (Gardner, \& Korth, 1997), engaging in reflection (Caferella, 2002; Gardner, \& Korth, 1997; Gilbert, \& Trudel, 2005), and using the problem-solving method (Mayer, \& Wittrock, 1996). Within the camp counseling program, there are two situations where transfer is desired: from training to the camp setting, and from camp counseling to future roles. It is this latter aspect that is of interest in the present study.

\section{Purpose}

The goals of the research were to examine the following areas from the alumni perspective:

1. their experiences as a 4-H camp counselor,

2. the life and workforce skills gained through their experience,

3. the transfer of these skills to other contexts,

4. the impact the camp counselor experience had on their career choice, and

5. the unique aspects of being a 4-H camp counselor as compared to the rest of the 4-H experience. 


\section{Methodology}

Little research has been conducted with the Ohio 4-H camp counselor program. Therefore, a qualitative research methodology was employed because, for this set of research questions, the insights, perceptions, and explanations of participants were considered more important than numbers (Krueger, 1994). Focus groups were selected because they allow the researcher to gain insight into individuals' thoughts, yet they allow for the dynamics of group interaction (Ary, Jacobs, \& Razavieh, 2002; Morgan, \& Krueger, 1993).

Procedures. The study procedures received approval by the university's Institutional Review Board. Extension Educators served as key informants in developing a list of potential focus group participants. In addition, members of Collegiate 4-H at The Ohio State University were recruited by visiting a club meeting and communicating with members via e-mail. Four focus groups were held in three geographic locations using procedures recommended by Morgan (1997) and Krueger (1998a, 1998b) and described in detail elsewhere (Digby, 2005). A moderator team, which consisted of a moderator and assistant moderator, facilitated all of the focus groups. All focus groups were taped recorded and transcribed for analysis.

Participants. From a total of 61 alumni contacted, 30 were available to participate in the focus groups. Those who could not participate indicated that they were obligated to work and family responsibilities. The average age was 22 years (ranging from 18 to 30 ), and the average number of years they were counselors was 4 years. Prior to serving as a camp counselor, they had been a camper for an average of five years. The sample was $100 \%$ Caucasian and twothirds female, which is consistent with the demographic profile for 4-H camp counselors in Ohio.

Measures. Focus group questions were developed by the researchers specifically for this study, adapting some questions from Garst and Johnson (2003, 2005). To gain an overall description of the experience, the introductory questions asked participants to reflect on their motivation to become a camp counselor and their favorite part of being a camp counselor. The transition questions asked participants to define life skills and explain their career goal and what they were doing to reach that career goal. The key questions asked the participants to describe the life skills gained and how they have been able to apply those skills to their current lives, the activities that helped the counselors develop those skills, and how the camp counseling experience has influenced their career decisions. Finally, counselors were asked about unique aspects of camp counseling.

Analysis. Initially, we used open coding to analyze the data (Strauss \& Corbin, 1990). Next we reviewed and categorized the "chunks" of data (i.e., words, phrases, or sentences). For the question related to skill development and transfer we used two frameworks to assist with coding these data: workforce skills (SCANS, 1991; see Table 1) and developmental experiences in organized youth activities (Dworkin, Larson, \& Hansen, 2003; Hansen, \& Larson, 2002). We found considerable overlap when cross-referencing these two sources, thus we were able to use the SCANS workforce competencies and foundation skills, with the addition of identity development, to encompass the range of skills learned. If discrepancies arose, we discussed them until we agreed on the appropriate coding. Once each question was analyzed, the data transcripts were reviewed for overarching themes. After analyzing the data from the four focus groups, we determined that the data had reached saturation, or the point where no new information was being collected (Morgan, 1997). 
Table 1

SCANS Competencies and Foundation Skills

\begin{tabular}{|l|l|}
\hline \multicolumn{1}{|c|}{ Competencies } & \multicolumn{1}{c|}{ Description } \\
\hline Resources & $\begin{array}{l}\text { Identifies, organizes, plans, and allocates time, money, material and } \\
\text { facilities, and human resources. }\end{array}$ \\
\hline Interpersonal & $\begin{array}{l}\text { Participates as a member of a team, exercises leadership, negotiates } \\
\text { with others, teaches others new skills, serves clients/customers, and } \\
\text { works with diverse populations. }\end{array}$ \\
\hline Information & $\begin{array}{l}\text { Acquires, evaluates, interprets, and communicates information; use } \\
\text { computers to process information. }\end{array}$ \\
\hline Systems & $\begin{array}{l}\text { Understands complex inter-relationships, designs or improves systems, } \\
\text { and monitors and corrects own performance. }\end{array}$ \\
\hline Technology & $\begin{array}{l}\text { Selects technology, applies technology, and maintains and } \\
\text { troubleshoots equipment. }\end{array}$ \\
\hline Foundation Skills & Description \\
\hline Thinking Skills & $\begin{array}{l}\text { Skills related to reading, writing, performing arithmetic and } \\
\text { mathematical operations, and listening and speaking }\end{array}$ \\
\hline Personal Qualities & $\begin{array}{l}\text { Skills related to creativity, making decisions, solving problems, } \\
\text { visualizing, self-directed learning, and reasoning }\end{array}$ \\
\hline $\begin{array}{l}\text { Individual displays responsibility, self-esteem, social skills, self- } \\
\text { management, and integrity and honesty. }\end{array}$ \\
\hline
\end{tabular}

Source: SCANS, 1991

The second author performed the initial coding of the data. A peer review process was used to establish validity. Both authors participated in the second phase of analysis to arrive at the skill categories by consensus. Discussion of the themes resulted in the conceptual model. Finally, we asked an experienced colleague who was not involved directly in the study to review the interpretations of the data and discuss any differences until they were resolved.

\section{Results and Discussion}

The results are presented in terms of the five aspects of the camp counseling experience that emerged from the data analysis: an overall description of the camp counseling experience, skill development and transfer, identity development, career development, and unique aspects.

\section{Overall Description of the Camp Counseling Experience}

Overall, 4-H camp counselors thought their experience was fun and enjoyable, yet challenging. Alumni enjoyed developing relationships with different age groups of campers and with counselors from other schools, teaching skills to campers, and watching campers learn. For example, alumni enjoyed watching shy campers open up and "come out of their shell." The counselors also thought the experience was rewarding because they were viewed as role models, and they liked the responsibility that came with their role of watching over the campers. Their own experiences as a camper provided motivation to be a counselor. As one former counselor looked back at her experiences she said, "I wanted to be just as special to the 
kids as they [my counselors] were to me when I was a camper." Many echoed the philosophy "camp is for the campers" that was ingrained in them as part of their training.

Even though alumni felt camp counseling was a positive experience, they described the challenges of working with a variety of different campers and their developmental needs (e.g., homesickness, ADHD). The amount of planning that went into a successful camp was surprising to some counselors, as they had not been aware of this as campers. Alumni agreed that the experience was exhausting at times, but worth it. As one alumnus stated,

You look back at the end of the week, and you are so glad that you experienced it but it's just really tiring.... Then you look back, it is so rewarding, and you think about all of the good experiences that you had and all the impacts you made, it doesn't make you feel tired anymore.

The availability of novel and interesting activities engages adolescents' active participation in youth programs. Furthermore, environments that offer challenging new opportunities for growth promote adolescent development (Eccles, at al., 1993). Adults facilitate young people's development when they offer the appropriate balance of support as youth take on new responsibilities (Eccles, \& Gootman, 2002; Larson, Hansen, \& Walker, 2005). It is also noteworthy that, unlike some groups (e.g., Bruce, Boyd, \& Dooley, 2005), the young people we interviewed appeared to be motivated by intrinsic rather than extrinsic rewards.

\section{Skill Development and Transfer}

Alumni believed they developed important life skills as a result of the camp counseling experience. One counselor noted that "when you are a camp counselor, there is no other time that you learn or use more life skills." A similar sentiment was expressed by another counselor:

Camp kind of allows you to draw all of your 4-H experiences together because it allows you to practice different skills throughout the week by being responsible in different ways and working with different people of different ages; it kind of just brings everything together.

More specifically, decision making, planning and organizing, communication, interpersonal skills, teamwork, and leadership were skills most mentioned. The following comments reflect the skills learned:

[I learned about] leading group projects, being able to work well with others, bringing everyone's ideas out, and public speaking on different committees.

I think one thing I learned was organization and also thinking about 'okay what do I need to do next.' Like kind of prioritizing, you know, like what needs to be done and thinking about what needs to come next so that you can plan your day and have everything done.

I learned how to teach, how to relay your message. [I learned] it was different if you were working with 9-year-olds versus explaining the same thing to your peers. You had to do it differently. 
These skills are consistent with other studies examining camp counselors' skill development. In terms of the SCANS (1991) categories, four of the five competencies and the three foundation skills categories were represented in our study. However, one category that did not emerge was that of technology. This is to be expected, because by its nature camp is a low-tech environment.

Some aspects of what was learned were categorized as personal qualities, such as responsibility, patience, and positive attitude. The SCANS Report (1991) considers personal qualities as one of the foundation areas needed for success in the workforce.

I think [I learned] responsibility. In the planning process, you said you were going to do something, and planning out the classes that you are going to teach, and whatever you were going to do during camp [you have to do] because everyone is relying on you to do it, and the responsibility of being there and taking care of all the kids and being the one that they go to when they get hurt or homesick or whatever those responsibilities are.

Not only did alumni learn these skills, they were transferred from one setting to another such as a student, employee, or community member. Alumni clearly could see that the skills they learned as part of being a camp counselor were applied to their daily lives. They noted leadership as the most prominent skill that has been applied to other contexts. For example, they were able to take the lead in group projects in college classes and extracurricular activities, take the lead in a job even when co-workers had the same responsibilities, and delegate tasks to others. In addition to those skills and personal qualities noted previously, the alumni also mentioned time management, initiative, and flexibility and adaptability. Following are representative quotes related to transfer of learning.

[Camp was] kind of like a life learning lesson because not only are you learning about taking care of little kids so you become a parent someday; also you are learning about diversity, how to work together on a team, taking leadership, and teaching campers.

Time management - at camp, there are a lot of things going on, you're taking campers to the pool, keeping crafts going. These skills have helped me manage homework, going to work, and class.

Even when you are a counselor and you are a group of leaders together, someone has to step up a lot, even when you are all working together doing the same thing. I have a couple of different duties in my job right now where there are two or three of us who do the same thing, and we are supposed to all work together and someone has always got to take the lead and be in charge of it. So that [being a camp counselor] helped me out a lot because I tend to be the one who ends up in the middle of that sort of thing.

[As a counselor you are] thinking on your toes, coming up with something really quick... [As a teacher] there are so many days when I have a lesson plan and it just fails and the kids just don't cooperate with it, and I just can't stand there and not do anything. I have to come up with something off the top of my head, and I 
think that definitely came from being a counselor for so many years and just doing that with the kids.

We learned...to make choices that help you make bigger choices later on.

While training was valuable, alumni believed they developed these skills and personal qualities by being actively engaged in their roles. This coincides with the idea that learning transfers best when it takes place in the context of real situations (Taylor, 1997). Furthermore, adults facilitated the counselors' development by how they treated them, as evidenced by the following comments:

I feel I gained a lot of self-respect. The adults respected our opinions....She asked for my help and I really appreciated that.

Counselors are just as important as adults, and it feels good to have that kind of responsibility.

Several alumni felt that reflection activities at the conclusion of camp helped them think about the skills learned as a camp counselor. For others, however, the reflection was not directly part of the camp experience. In one example, a counselor related how she realized she had learned various skills when she was preparing college scholarship applications.

Sometimes, learning occurred due to a negative experience. Having to dealing with adversity taught them how to "roll with the punches....that your attitude, the way you dealt with it, affected others' responses." Another counselor related a serious situation that occurred during camp that she described as "the worst experience." However, getting through it left her feeling "I can do anything after that."

\section{Identity Development}

Alumni described their experience as one of personal growth. Being a camp counselor was the first time many alumni got to try out new roles and learn more about themselves. A comment by one counselor showed this process: "[I learned about] the dynamics of the situation. It's like an intricate puzzle: the balance between having fun and being safe, being with peers and being responsible for younger campers."

The camp setting was conducive to identity exploration in that "you have the opportunity to laugh at yourself and you find out who you really are," and you have the chance "to be a completely different person if you want." As they reflected back, alumni realized that adults had put a considerable amount of trust in them to fulfill important responsibilities. Being given the responsibility of leading and teaching activities for campers as a teenager was significant for them.

Identity development is a major adolescent developmental task (Harter, 1993; Kroger, 2000; McIntosh, Metz, \& Youniss, 2005; Thomas, 1992). Researchers concur that opportunities to hold meaningful roles and carry out real responsibilities are important to adolescents, as they are critical to the development of both initiative and identity (Eccles, \& Gootman, 2002; Kroger, 2000; Larson, 2000). Based on the counselors' descriptions, these conditions were present in their camp experience. 


\section{Career Development}

The opportunity to try out new roles allowed alumni to learn more about the type of job environment where they wanted to work, which had an indirect impact on their career choices. One counselor stated that she learned "you can have a job that you enjoy" and she now has such a job working as a residence hall director. Another counselor wanted to re-create the feeling of "the reward at the end of the day" that he experienced as a camp counselor.

Still other alumni felt that the camp counseling experience had a more direct impact on their career choice, as they chose to enter careers that involved working with people, especially in formal and nonformal education. For example,

[Because of camp] I knew right away that I wanted to work with people; it suits me. [My career goal is] human resources, I want to train. I fell in love with training through team building through 4-H. I want to give presentations, help people be better employees, and help employers create a better working environment.

Wanting to be a middle school teacher is totally based on my camp counselor experience. I learned that I like $5^{\text {th }}, 6^{\text {th }}$, and $7^{\text {th }}$ graders the best, although others think I'm crazy!

I decided that I really liked kids and I could be around them all day, but I also decided that I like having a say in things, so the job I have now [as a child care facility manager] is a good blend of things.

These findings contrast with those of Brandt and Arnold (2006), who found that counselor alumni did not think their experience as a counselor prepared them for working with children. However, our findings lend support to what the counselors in Forsythe, et al.'s (2004) study said regarding their future careers. Nearly all of the counselors in their study could identify at least one skill that would help them in a future job.

The descriptions given by the alumni reinforced Ferrari and McNeely's (2007) conclusion that the experience of camp counseling represents an example of stage-environment fit, that is, an activity that fits well with the developmental needs of its participants (Eccles et al., 1993). It is a time when adolescents need to develop the attitudes, competencies, values, and social skills that will help them be successful adults, and camp counseling provides one such mechanism to navigate this developmental pathway.

\section{Unique Aspects}

One of the unique aspects of being a camp counselor compared to other experiences in 4-H was that camp takes place in an environment where there is little competition. The camp environment was described as fun, and as having an intangible quality, "something magical" about it. Camp counselors also have the opportunity to "sign on" as leaders and role models, and camp counselors felt that this responsibility was greater than any other aspect of $4-\mathrm{H}$. They were aware that this was a very real, "authentic" responsibility:

We as counselors plan camp and run camp. Adults supervise and we have to step up to our roles. Camp goes on how well counselors do. 
Counselors noted that they made lasting friendships with others. Relationships that developed at camp between the camp counselors and between and the counselors and the campers were more intense. It is these relationships that keep counselors coming back to camp because "they feel like they made a difference, and they feel like they are doing good things." This was due to the opportunity to work one-on-one with people. Alumni noted the unique, 24/7 nature of camp living as well as the new experiences that are part of it.

At camp, you really get to see what people are really like because you are together night and day, all that time.

It is a lot of up and downs like life in general, but it is so compact because it is all in a week.

[I think] it is the physical environment and the newness and difference of the experiences.

Furthermore, if conflicts developed in a cabin, there was no escape from it. As one alumnus stated, "If you're not enjoying your cabin experience, you are stuck in there for a week, and you are going to have to grow and learn how to deal with whatever bad things are going on."

\section{Conceptual Model}

Figure 1 describes what we believe is happening within the 4-H camp counseling experience, based on the themes derived from this study's data. As adolescents, camp counselors are highly engaged in their roles and activities at camp. In turn, camp counselors believed they developed teamwork and social skills, initiative, identity, and interpersonal skills. The skills from this experience are then transferred over time to other contexts of their lives. Because having such significant responsibility placed on them is a new experience, camp counselors can be said to grow into, and also grow from, the experience. The data presented here show that when they reflected on their time as a camp counselor, alumni believed their experiences have helped them to develop important skills and personal qualities that they use in their current life. This development has happened across the dimension of time, and was aided by various transfer of learning strategies that, intentionally or unintentionally, were part of the camp counseling experience. 
Figure 1

A Conceptual Model: The 4-H Camp Counseling Experience

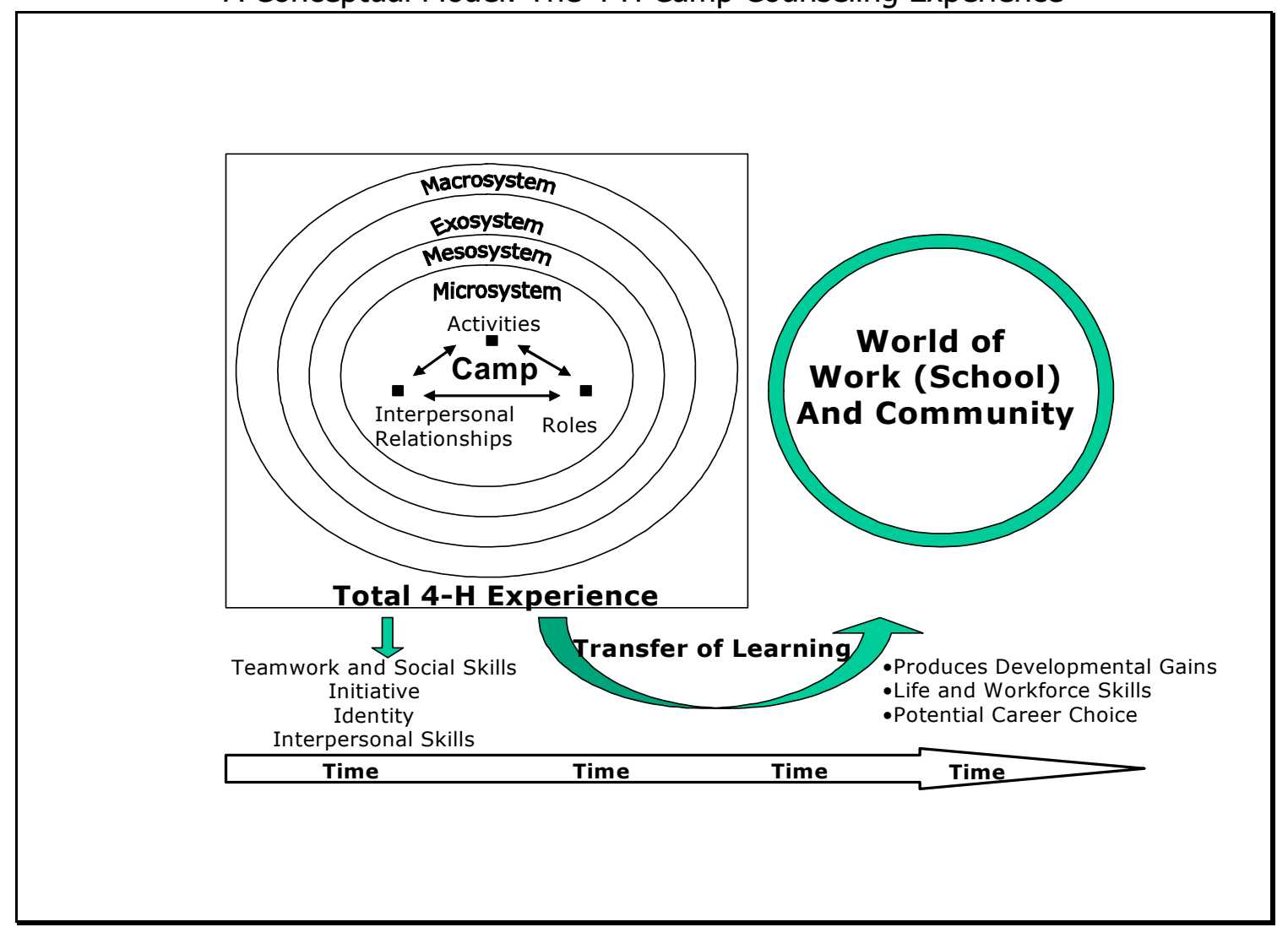

\section{Implications}

The purpose of this study was to elicit 4-H camp counselor alumni views of their camp counseling experience in relation to the skills they developed, the transfer of these skills to the workforce, and the impact of camp counseling on career choices. The results of this study should be viewed in light of several limitations. It was not practical to question all 4-H camp counselor alumni about their experiences. Therefore, the study results cannot be generalized to the entire population of alumni 4-H camp counselors in Ohio. Alumni may tend to remember their experiences in a positive light. The skills alumni developed are based on self-report rather than objective measures. However, given that the purpose of this study was to gain counselors' perspective, this qualitative study provided a more in-depth look at the nature of the experience. Furthermore, it could be argued that by definition, far transfer does not occur until counselors find themselves in new situations where they apply the skills they have learned, thus an alumni study provides a unique vantage point from which to examine this concept.

\section{Implications for Research}

There are several implications for future research. To gain a broader perspective regarding the experiences described here, a survey research design could be developed. Themes generated from the present study could form the basis for questions on such a survey. 
Because transfer of skills is important in the short- and long-term, camp counselor training is another area of research that needs to be addressed. Using concepts from transfer of learning research as a framework, research questions could look at the techniques used in training and how that training aids camp counselors in developing skills. Much of the transfer of learning research has been conducted on children's academic learning in specific subject areas (e.g., mathematics; Fuchs, et al., 2003), or with adults, for example in the areas of computers (Olfman, \& Shayo, 1997), medical education (Hmelo, 1998), and coaching (Gilbert, \& Trudel, 2005). There appears to be a lack of research about the process-type skills (i.e., life skills) posited to occur within the community-based, out-of-school learning environments typical of the 4-H program. That is, much of the research with youth occurs in highly-structured situations, which may be necessary for experimental designs, but it does not reflect the complex nature of real world programs. Thus, studies of the training that is part of the 4-H camp counselor experience could contribute new knowledge to what constitutes effective educational practices, especially in nonformal settings. This is especially important given the suggestion that such settings provide ideal contexts for workforce skill development (Schwarz, \& Stolow, 2006).

Another promising avenue of future research can be gleaned from the comment made by one alumnus: "You've just got to come and find out what it's all about." Direct observation of youth as they prepare for and engage in their camp counseling roles would provide a perspective not available through other research methods. Such a study would parallel the program of research undertaken by Larson and his colleagues, which has yielded rich description of the processes by which youth programs serve as contexts for positive development (e.g., Dworkin, et al., 2003; Jarrett, Sullivan, \& Watkins, 2005; Larson, \& Hansen, 2005; Larson, Hansen, \& Walker, 2005; Larson, Jarrett, et al., 2005; Larson, \& Walker, 2006; Larson, Walker, \& Pearce, 2006; Pearce, \& Larson, 2006). Observations of a program with the unique features of the camp setting (i.e., a residential experience in the natural environment) might provide additional insights.

\section{Implications for Practice}

This study suggests many practical applications for those who work with camp programs.

1. To make adolescents aware of skills needed for the workforce, this topic should be included as part of camp counselor training. Counselors may incorrectly believe that the only careers that their camp experience prepares them for are those directly related to the camping industry or to working with children. Specific opportunities for reflection would enable counselors to understand skills valued by employers and that they had developed these skills through their camp experiences.

2. Learning depends on having a base of content knowledge and procedural skills, that is, the skills necessary to solve problems (Basile, 2000). Thus, camp counselor training must provide not only the necessary background knowledge but also practice in applying the skills needed to handle the range of teaching and supervising situations counselors are likely to encounter.

3. To ensure that transfer of learning is intentional, specific strategies can be incorporated into the design of counselor training. For transfer to occur, camp directors must provide experiences that are real and meaningful. Alumni also indicated that actually doing activities was perhaps the most helpful. The literature suggests that these strategies may include lessons that actively engage participants and allow them to reflect on their experiences. 
4. Adults need to give youth ownership over their roles and responsibilities in order for significant development to occur. However, they need to provide appropriate structure and guidance to teens as they assume these new roles.

5. Alumni indicated that challenging activities were important. To ensure increasing levels of challenge, camp directors should consider expanding youth leadership roles as counselors become more experienced. For example, they may become involved in conducting aspects of the training (Homan, 2005) and mentoring younger counselors.

6. Camp directors should be aware of the importance of initiative to adolescent development. Many jobs available to teens do not provide opportunities for initiative to develop (Bryant, Zvonkovic, Raskauskas, \& Peters, 2004). Thus, young people need to develop such competencies in other ways. The conditions present in the camp counseling experience - motivation and focused attention - make it an ideal setting to develop initiative (Larson, 2000). The literature suggests several practices to use when working with teens to help them develop skills in working with others and to develop initiative, such as following youths' lead, asking guiding questions, providing intermediate structures, and monitoring youth to keep them on track (Larson, Hansen, \& Walker, 2005).

7. Camp counselors could complete a self-assessment of their skills, which would provide an opportunity for reflection. In addition, camp directors could meet with counselors after camp to provide constructive feedback about their performance. This approach has been used in other work-based learning programs with teens (e.g., Cochran, Arnett, \& Smathers, 2006). Both of these techniques would reinforce the workforce connections between camp counseling and future employment.

8. Communicate to stakeholders that camp counseling is more than fun and games; it prepares teens with valuable workforce skills such as communication, teamwork, planning, and decision making.

\section{Summary}

In summary, this study adds to the growing body of literature on 4-H camping. It demonstrates that camp counseling provides a challenging, meaningful role through which adolescents develop their identity and career potential. The experience of being a camp counselor contains the features that provide youth with a positive context for development. Camp counseling translates into pathways to a positive future, as skills are transferred to other contexts, such as work and community life. Therefore, camp presents a setting for teens to thrive: a safe place for them to practice cognitive skills and explore their identity through diverse activities and interaction with people. Furthermore, this study lends support to viewing camp counseling from the theoretical perspectives of human ecological theory and transfer of learning. It is easy to see why it has been described as "the experience of a lifetime." 


\section{References}

American Camp Association. (2005). Directions: Youth development outcomes of the camp experience. Martinsville, IN: Author. Retrieved from the American Camp Association http://www.acacamps.org/research/directions.pdf

Arnold, M.E., Bourdeau, V.D., \& Nagele, J. (2005). Fun and friendship in the natural world: The impact of Oregon residential camping programs on boy and girl campers. Journal of Extension [On-line], 43(6), Article No. 6RIB1. Available at:

http://www.joe.org/joe/2005december/rb1.shtml

Ary, D.A., Jacobs, L.C., \& Razavieh, A. (2002). Introduction to research in education (6 $6^{\text {th }}$ ed.). Belmont, CA: Wadsworth/Thomson Learning.

Basile, C.G. (2000). Environmental education as a catalyst for transfer of learning in young children. Journal of Environmental Education, 32(1), 21-27.

Battelle Memorial Institute. (2005). Ohio State University Extension: A generator of economic impacts for Ohio. Available at: http://extension.osu.edu/about/executive summary.pdf

Brandt, J. (2005, November). The effect of participation of youth in camp counselor programs. Presentation at the National Association of Extension 4-H Agents annual conference, Seattle, WA. Retrieved from http://nae4ha.wsu.edu/abstracts/A yd32.htm

Bronfenbrenner, U. (1979). The ecology of human development: Experiments by nature and design. Cambridge, MA: Harvard University Press.

Bronfenbrenner, U., \& Morris, P.A. (1998). The ecology of human developmental processes. In W. Damon (Series Ed.) \& R.M. Lerner (Vol. Ed.), Handbook of child psychology: Vol. 1. Theoretical models of human development (5th ed., pp. 993-1028). New York: Wiley.

Bruce, J.A., Boyd, B.L., \& Dooley, K.E. (2005). Evaluation of transfer of training and skills learned as State 4-H Council members. Journal of Leadership Education [On-line], 4(1), 51-61. Retrieved from http://www.fhsu.edu/jole/issues/JOLE 4 1.pdf

Bryant, B., Zvonkovis, A., Raskauskas, J., \& Peters, C. (2004). Clarifying the world of work for our youth: Vocations, careers, and jobs. Davis, CA: University of California, Center for Youth Development. Retrieved from http://fourhcyd.ucdavis.edu/publications/pubs/focus/pdf/M004V9N1.pdf

Caffarella, R.S. (2002). Planning programs for adult learners ( $2^{\text {nd }}$ ed.). San Francisco, CA: Jossey-Bass.

Carlson, S., \& Maxa, S. (1998). Pedagogy applied to nonformal education. The Center, Winter 1998, 48-53. Retrieved from the University of Minnesota's Center for 4-H Youth Development website: http://www.fourh.umn.edu/resources/center/PDF/Center-Story9.pdf 
Casner-Lotto, J., \& Barrington, L. (2006). Are they really ready to work? Employers' perspectives on the basic knowledge and applied skills of new entrants to the $21^{\text {st }}$ century U.S. workforce. New York: The Conference Board. Available at: http://www.conferenceboard.org/pdf free/BED-06-Workforce.pdf

Cochran, G., Arnett, N., \& Smathers, C. (2006, May). 4-H workforce prep: Real jobs, meaningful experiences, and marketable skills. Workshop presented at the Children, Youth, and Families at Risk (CYFAR) annual conference, Atlanta, GA.

DeGraaf, D., \& Edington, C.R. (1992). Work motivation and camp counselors. Journal of Park and Recreation Administration, 10(4), 37-56.

DeGraaf, D., \& Glover, J. (2003). Long-term impacts of working at an organized camp for seasonal staff. Journal of Park and Recreation Administration, 21(1), 1-20.

Digby, J.K. (2005). "The experience of a lifetime": Alumni perceptions of the development and transfer of life and workforce skills in the Ohio 4-H camp counselor program. Unpublished master's thesis, The Ohio State University, Columbus.

Dworken, B.S. (2004, February). The unique contributions and impacts of the camp staff experience. Presentation at the American Camp Association Camp Research Symposium, San Francisco, CA. Retrieved from http://www.acacamps.org/research/CRS handouts 2004.pdf

Dworkin, J.B., Larson, R., \& Hansen, D. (2003). Adolescents' accounts of growth experiences in youth activities. Journal of Youth and Adolescence, 32(1), 17-26.

Eccles, J., \& Gootman, J.A. (Eds.). (2002). Community programs to promote youth development. Washington, DC: National Academy Press.

Eccles, J.S., Midgely, C., Wigfield, A., Buchanan, C.M., Reuman, D., Flanagan, C., et al. (1993). Development during adolescence: The impact of stage-environment fit on adolescents' experiences in schools and families. American Psychologist, 48, 90-101.

Ferrari, T.M. (2003). Working hand in hand: Community youth development and career development. In F.A. Villarruel, D.F. Perkins, L.M. Borden, \& J.G. Keith (Eds.), Community youth development: Programs, policies, and practices (pp. 201-223). Thousand Oaks, CA: Sage.

Ferrari, T.M., \& McNeely, N.N. (2007). Positive youth development: What's camp counseling got to do with it? Findings from a study of Ohio 4-H camp counselors. Journal of Extension, 45(2), Article No 2RIB7. Available at: http://www.joe.org/joe/2007april/rb7.shtml

Forsythe, K., Matysik, R., \& Nelson, K. (2004, May). Impact of the 4-H camp counseling experience. Department of Youth Development, University of Wisconsin-Extension, Madison, WI. Retrieved from http://www.uwex.edu/ces/4h/department/viewdocument.cfm?item=Impact\%20of\%20the\%204 \%2DH\%20Camp \%20Counseling\%20Experience\%2Epdf 
Fuchs, L.S., Fuchs, D., Prentice, K., Burch, M., Hamlett, C.L., Owen, R., et al. (2003). Explicitly teaching for transfer: Effects on third-grade students' mathematical problem solving. Journal of Educational Psychology, 95(2), 293-305.

Gardner, B.S., \& Korth, S.J. (1997). Classroom strategies that facilitate transfer of learning to the workplace. Innovative Higher Education, 22(1), 45-60.

Garst, B.A., \& Bruce, F.A. (2003). Identifying 4-H camping outcomes using a standardized evaluation process across multiple 4-H educational centers. Journal of Extension [On-line], 41(3). Available at: http://www.joe.org/joe/2003june/rb2.shtml

Garst, B.A., \& Johnson, J. (2003, February). Impacts of residential camp counseling on adolescent leadership skills development. Presentation at the American Camp Association Camp Research Symposium, Denver, CO. Retrieved from the American Camp Association website http://www.acacamps.org/research/03symposium.pdf

Garst, B.A., \& Johnson, J. (2005). Adolescent leadership skill development through residential 4H camp counseling. Journal of Extension [On-line], 43(5), Article No. 5RIB5. Available at: http://www.joe.org/joe/2005october/rb5.shtml

George, J., \& Bird, M. (2006, October). Youth development outcomes of the camp experience: Initial findings of the California 4-H Camping Task Force. Seminar presented at the National Association of Extension 4-H Agents annual conference, Milwaukee, WI.

Gilbert, W.D., \& Trudel, R. (2005). Learning to coach through experience: Conditions that influence reflection. The Physical Educator, 62(1), 32-43.

Hansen, D.M., \& Larson, R.W. (2002). The Youth Experiences Survey 1.0: Instrument development and testing. Unpublished manuscript, University of Illinois. Retrieved from the University of Illinois Youth Development Research Project http://web.aces.uiuc.edu/youthdev/yes.htm

Harter, S. (1993). Self and identity development. In S.S. Feldman \& G.R. Elliott (Eds.), At the threshold: The developing adolescent (pp. 352-387). Cambridge, MA: Harvard University Press.

Haskell, R.E. (2001). Transfer of learning: Cognition, instruction, and reasoning. San Diego, CA: Academic Press.

Hmelo, C.E. (1998). Problem-based learning: Effects on the early acquisition of cognitive skill in medicine. The Journal of the Learning Sciences, 72), 173-208.

Homan, G. (2005, November). 4-H camp counselor trainers, an expanded leadership role. Poster session presented at the National Association of Extension 4-H Agents annual conference, Seattle, WA. Abstract retrieved from

http://nae4ha.wsu.edu/abstracts/Mon p02.htm 
James, J.J. (2003, February). The threshold for staff transformation: An ethnography of Girl Scout camp staff. Presentation at the American Camp Association Camp Research Symposium, Denver, CO. Retrieved from American Camp Association website http://acacamps.org/research/03symposium.pdf

Jarrett, R.L., Sullivan, P.J., Watkins, N.D. (2005). Developing social capital through participation in organized youth programs: Qualitative insights from three programs. Journal of Community Psychology, 33(1), 41-55.

Kroger, J. (2000). Identity development: Adolescence through adulthood. Thousand Oaks, CA: Sage.

Krueger, R.A. (1994). Focus groups: A practical guide for applied research $\left(2^{\text {nd }}\right.$ ed.). Thousand Oaks, CA: Sage.

Krueger, R.A. (1998a). Developing questions for focus groups. Thousand Oaks, CA: Sage.

Krueger, R.A. (1998b). Moderating focus groups. Thousand Oaks, CA: Sage.

Larson, R.W. (2000). Toward a psychology of positive youth development. American Psychologist, 55(1), 170-183.

Larson, R., Jarrett, R., Hansen, D., Pearce, N., Sullivan, P., Walker, K., Watkins, N., \& Wood, D. (2005). Organized youth activities as contexts for positive development. In A. Linley \& S. Joseph (Eds.), Positive psychology in practice: From research to application (pp. 540-560). New York: Wiley.

Larson, R., \& Hansen, D. (2005). The development of strategic thinking: Learning to impact human systems in a youth activism program. Human Development, 48, 327-349.

Larson, R., Hansen, D.M., \& Walker, K. (2005). Everybody's gotta give: Adolescents' development of initiative within a youth program. In J. Mahoney, J. Eccles, \& R. Larson (Eds.), After-school activities: Organized activities as contexts of development (pp. 159-183). Hillsdale, $\mathrm{NJ}$ : Lawrence Erlbaum.

Larson, R.W., \& Walker, K.C. (2006). Learning about the "real world" in an urban arts youth program. Journal of Adolescent Research, 21(3), 244-268.

Larson, R., Walker, K., \& Pearce, N. (2005). A comparison of youth-driven and adult-driven programs: Balancing inputs from youth and adults. Journal of Community Psychology, 33(1), 57-74.

Levy, F., \& Murnane, R.J. (2006). Why the changing American economy calls for twenty-first century learning: Answers to educators' questions. New Directions for Youth Development, No. $110,53-62$.

Macaulay, C. (2000). Transfer of learning. In V.E. Cree \& C. Macaulay (Eds.), Transfer of learning in professional and vocational education (pp. 1-26). New York: Routledge. 
Mayer, R.E., \& Wittrock, M.C. (1996). Problem-solving transfer. In D.C. Berliner \& R.C. Calfee (Eds.), Handbook of educational psychology (pp. 47-62). New York: Macmillan Library Reference.

McIntosh, H., Metz, E., \& Youniss, J. (2005). Community service and identity formation in adolescents. In J.L. Mahoney, R.W. Larson, \& J.S. Eccles (Eds.). Organized activities as contexts of development: Extracurricular activities, after-school and community programs (pp. 331-352). Mahwah, NJ: Lawrence Erlbaum Associates.

McKinley, S.K. (1999). 4-H alumni perceptions regarding the impact of the Indiana 4-H program. Unpublished doctoral dissertation, Purdue University, West Lafayette, IN.

McNeely, N.N. (2004). The Ohio 4-H camp counseling experience: Relationship of participation to personal, interpersonal, and negative experiences. Unpublished doctoral dissertation, The Ohio State University, Columbus. Available at: http://www.ohiolink.edu/etd/view.cgi?osu1095800892

Mitchell, A.V., \& Meier, J.F. (1983). Camp counseling: Leadership and programming for the organized camp ( $6^{\text {th }}$ ed.). Philadelphia: Saunders College Publishing.

Morgan, D.L. (1997). Focus groups as qualitative research ( $2^{\text {nd }}$ ed.). Thousand Oaks, CA: Sage.

Morgan, D. L., \& Krueger, R.A. (1993). When to use focus groups and why. In D.L. Morgan (Ed.), Successful focus groups (pp. 1-19). Newbury Park, CA: Sage.

Murnane, R.J., \& Levy, F. (1996). Teaching the new basic skills: Principles for educating children to thrive in a changing economy. New York: Free Press.

Nokes, T.J., \& Ohlsson, S. (2005). Comparing multiple paths to mastery: What is learned? Cognitive Science, 29, 769-796.

Olfman, C., \& Shayo, C. (1997). The role of training in preparing end users to learn new but similar software packages. Proceedings of the 1997 ACM SIGCPR (Special Interest Group on Computer Personnel Research) Annual Conference, San Francisco, CA, pp. 210-223.

Partnership for $21^{\text {st }}$ Century Skills. (2003). Learning for the $21^{\text {st }}$ century. Washington, DC: Author. Retrieved from http://www.21stcenturyskills.org/images/stories/otherdocs/P21 Report.pdf

Pearce, N.J., \& Larson, R.W. (2006). How teens become engaged in youth development programs: The process of motivational change in a civic activism organization. Applied Developmental Science, 10(3), 121-131.

Pittman, K.J., Irby, M., Yohalem, N., \& Wilson-Ahlstrom, A. (2004). Blurring the lines for learning: The role of out-of-school programs as complements to formal learning. New Directions for Youth Development, 101, 19-41. 
Powell, G.M., Bixler, R.D., \& Switzer, D.M. (2003). Perceptions of learning among new and returning seasonal camp staff. Journal of Park and Recreation Administration, 21(1), 61-74.

Purcell, L.E. (1996). Does participation in the Georgia 4-H counselor program increase leadership life skills development? Unpublished master's thesis, University of Georgia, Athens.

Salomon, G., \& Perkins, D.N. (1989). Rocky road to transfer: Rethinking mechanisms of a neglected phenomenon. Educational Psychologist, 24(2), 113-142.

Secretary's Commission on Achieving Necessary Skills (SCANS). (1991). What work requires of students. Washington, DC: U.S. Department of Labor. Retrieved from http://wdr.doleta.gov/SCANS/whatwork/whatwork.pdf

Schwarz, E., \& Kay, K. (2006). Issue editors' notes. New Directions for Youth Development, No. $110,1-7$.

Schwarz, E., \& Stolow, D. (2006). Twenty-first century learning in afterschool. New Directions for Youth Development, No. 110, 81-99.

Strauss, A., \& Corbin, J. (1990). Basics of qualitative research: Grounded theory procedures and techniques. Newbury Park, CA: Sage.

Taylor, M. (1997). Transfer of learning: Planning effective workplace education programs (ERIC ED 414 462). Ottawa, Ontario, Canada: National Literacy Secretariat.

Thomas, R.M. (1992). Comparing theories of child development (3rd ed.). Belmont, CA: Wadsworth.

Toupence, R.H., \& Townsend, C.D. (2000, January). Leadership development and youth camping: Determining a relationship. In L.A. Stringer, L.I. McAvoy, \& A.B. Young (Eds.), Coalition for Education in the Outdoors Fifth Biennial Research Symposium Proceedings, Bradford Woods, IN (pp. 82-88). Cortland, NY: Coalition for Education in the Outdoors.

Weese, M.A. (2002). The effects of the Jefferson County 4-H camp teen leader training and camp experience on the teen participants' internal assets of positive values, social competencies and positive identity. Unpublished doctoral dissertation, University of Louisville, Louisville, KY.

(C) Copyright of Journal of Youth Development Bridging Research and Practice. Content may not be copied or emailed to multiple sites or posted to a listserv without copyright holder's express written permission. Contact Editor at: patricia.dawson@oregonstate.edu for details. However, users may print, download or email articles for individual use.

ISSN 2325-4009 (Print); ISSN 2325-4017 (Online) 